\title{
The Effect of Market Orientation and Entrepreneurial Orientation on the New Product Development
}

\author{
Adisu Fanta Bate \\ University of Pécs
}

\section{THE AIMS OF THE PAPER}

The researches on the effect of Market Orientation (MO) and Entrepreneurial Orientation (EO) on firms' performance have demanded much effort in marketing researches and unparalleled results have been observed depending up on the context of the studies. But, it seems that much attention has not been given to the effect of these orientations in New Product Development (NDP), applying various forms and approaches of innovation, which is the stem for the overall performance of firms. Hence, this paper aimed to identify different forms and approaches of innovation in NPD and to explain the role or effect of EO and MO on NPD with respect to these forms and approaches of innovation.

\section{METHODOLOGY}

Literatures published from 1980 to 2018 in various databases (Business source Premier, Scopus, Web of Science, Science Direct and Academic Search Complete) were accessed and over forty publications were synthesized using systematic literature survey.

\section{MOST IMSPORTANT RESULTS}

The product innovation forms and approaches such as discontinuous versus continuous, radical versus incremental, market-driven innovation versus driving-market innovation, and pure product innovation versus marketing mix-product innovation are identified. In the case of discontinuous (also called disruptive or radical) innovation and pure product innovation forms and driving-market innovation approaches, the role of EO outweighs MO in NPD and the latter may not be even useful in these cases. In contrast to MO, EO makes firms pro-active, innovative and to take risk that leads to ground breaking product innovation. On the other hand, in the case of continuous (also called incremental) innovation, and marketing-mix related product innovation forms and market-driven innovation approaches of innovation, it is MO that plays prominent role and equips firms with up to date market intelligence from customers, competitors and suppliers. Literature also adequately supports that MO makes firms competitive in the market and helps them to cope with the existing market system.

\section{RECOMMENDATIONS}

Both $\mathrm{MO}$ and $\mathrm{EO}$ are important for product innovation but their application and the extent of their role or contribution varies depending on the approaches and forms of product innovation adopted, and it is not the issue of being complementary to each other or not as most studies argued. Therefore, practitioners, first, need to know the approaches and forms of innovation they needed before relying either in EO or MO. This study focused on product innovation from manufacturers' points of view but further empirical research can be done involving service sector organizations regarding the unique roles of $\mathrm{EO}$ and $\mathrm{MO}$.

Keywords: market orientation, entrepreneurial orientation, new product development, innovation

DOI: https://doi.org/10.15170/MM.2019.53.02.04 


\section{INTRODUCTION}

According to Schilling and Hill (1998), for many industries, new product development is now the single most important factor driving firm success or failure. The authors argue that researchers from strategic management, engineering, marketing, and other disciplines give emphasis on new products and new product development process. In fact, new product development is not an activity but it is a process which incorporates sets of activities and various groups of people. Frishammar (2005) defines a New Product Development (NPD) process as a sequence of information processing activities. But he remarked that the information in NPD occupies a much broader conceptual space than the reduction of uncertainty. The information about NPD can be obtained by reviewing the literature and scanning business environment, market, gatekeepers, crossfunctional integration, and knowledge repository.

In general, it is believed that NPD always needs to utilize important resources mainly the information about market conditions. In a cross national study conducted by Calantone et al. (1996), they have shed light on the importance of collecting and assessing market and competitive information in order to identify clients' wants, demands, level of price sensitivity and product preference and to get the weaknesses, strength, core competencies and competitive strategies of competitors. These are altogether called Market Orientation (MO), without which a firm cannot achieve its two critical objectives: maximizing the fit with customers' needs and minimizing time to market (Schilling \& Hill 1998).

Maximizing the fit with customers' needs, especially, refers to market orientation of a firm and it is typically measured by assessing firms' commitment to base strategic decisions on customer-oriented market intelligence (Baker and Sinkula 2009). These researchers indicated that firms with strong MO prioritize on learning about customers' likes and dislikes, satisfaction and perception in order to produce and satisfy them with tailor-made products and services. Moreover, MO is not only limited to knowing about customers but also it includes orientation about competitors and suppliers. MO encompasses four main activities: intelligence generation, intelligence dissemination, intelligence integration and coordinated action (Slater et al. 2010). In previous researches, MO consists of three elements: intelligence generation, dissemination, and responsiveness (Kohli \& Jaworski 1990, Slater \& Narver 1995, Atuahene-Gima 1996, Jaworski et al. 2000).
In intelligence generation process, market-oriented firms solicit a diversified range of intelligence about influential market forces. Market intelligence generally indicates all useful information about market trends and actors in the market including current and future customer needs which is often known as Customer Analysis; competitors' capabilities and strategies (i.e. is known as Competitor Analysis); and other important influencers, such as suppliers (Slater et al. 2010). It seems that MO has been found to be the most important component to be considered in new product development in order to satisfy customers with customer-oriented product. Considering the needs and wants of customers, the level of competition with rivals and the availability of resource with suppliers could play prominent role in firm performance in general and for new product development in particular (Baker and Sinkula 2002, as cited in Baker \& Sinkula 2009).

However, it has been made clear that MO is not the only factor which determines the success or failure of new product development as well as company profitability. There are still areas which are not addressed with MO that firms needs to be aware of like innovativeness, pro-activeness, risk taking, autonomy and aggressive competitiveness, which are generally recognized and known as Entrepreneurial Orientation (EO) (Lumpkin and Dess, 1996; Awang et al. 2010); and the first three are most commonly regarded by scholars as EO dimensions (Zahra 1991, Covin \& Slevin 1986, Rauch et al. 2009). EO has evolved as the other important aspect to be considered whether to develop a new product or increase firms' profitability. According to Scott \& Venkataraman (2000), EO reflects the prioritization that business organizations follow in the process of identifying and exploiting business opportunities.

Perhaps, MO and EO have overlapping, but distinct domains (Slater and Narver 1995). As per their explanation, $\mathrm{MO}$ is posited to reflect the extent to which firms establish the satisfaction of customer needs and wants as an organizing principle of the firm. Whereas, EO is posited to reflect the extent to which firms establish the identification and exploitation of untapped opportunities as an organizing principle of the firm. Also, both orientations require and embrace learning to be operational (Baker et al. 2009), which is almost to the idea posed by Scott \& Venkataraman (2000). And in their literature review, they have come to make a conclusion that $\mathrm{MO}$ and $\mathrm{EO}$ are correlated, but distinct constructs or distinct domains (Baker et al. 2009, Slater and Narver 1995). Because of their distinct domains or 
constructs, these orientations do not have an equal or the same contribution in all approaches and forms of innovation in NPD. This paper deals with the effect of these orientation on different forms and approaches of innovation in NPD. First, various forms and approaches of product innovation were identified and then role or effects of $\mathrm{EO}$ and $\mathrm{MO}$ in NPD were discussed considering various forms and approaches of innovation. In short, it answers the questions: what are the various forms and approaches of product innovation in NPD? How do EO and $\mathrm{MO}$ affect or contribute in those different forms and approaches of innovation in NPD?

\section{RESEARCH METHODOLOGY}

As discussed above, research activities on the roles of $\mathrm{MO}$ and $\mathrm{EO}$ on firm performance has attracted much attention over decades from several researchers, academicians and practitioners. This article aims to find out the unique roles played by $\mathrm{MO}$ and EO in new product development or product innovation. To achieve this, the research systematically reviewed peer reviewed articles published in reputable journals. The search query that incorporated important terms: market orientation, entrepreneurial orientation and new product development or product innovation was used in a number of databases including Science Direct, Business Source Premier, Web of Science, Academic Search Complete and Scopus. To get recent trends, the search for articles was narrowed to the period 1980 to 2018, and a total of 40 articles were accessed and reviewed.

\section{THE NEW PRODUCT DEVELOPMENT (NPD)}

Most commonly in marketing literature, the terms innovation and new product development have been used interchangeably (Iyer et al. 2006). Hence, in this article, the same conceptual approach is adopted. Through time, new product development and its process has become the main strategic issue for competitive manufacturing as well as marketing organizations. The survey findings of Product Development and Management Association indicate that NPD process continues to evolve and become sophisticated (Griffin 1997). Her research also points out that NPD changes continually on multiple fronts and those businesses that fail to keep up to date their NPD practices would be suffering from both unexpected and expected market competitive shortcomings. The globalization of economy and the segregation of markets into ever smaller niches could be considered as main causes behind the unprecedented increase of emphasis on new product development as competitive dimension (Schilling \& Hill 1998).

In fact, different companies may have their own unique NDP process or practices based on the nature of products they develop and their target markets. The interest of this paper is not on the best practices in NPD process; rather it gives emphasis on the product innovation forms and approaches and shows the effects of both MO and EO on various product innovations of firms. Also, herewith in this article, the new product development (NPD) is analyzed from manufacturers' point of view; and not from the marketer's. In general, manufacturer can be understood as a company which is the creator of new product whereas marketer can be considered as a company or set of companies working to connect and introduce an innovative product or service to the target customers. For new production managers of firms, there is no issue more fundamental than understanding the factors that separate success from failure in new product development (Cooper \& Kleinschmidt 1987). One of these factors is the approach of innovation that is adopted in NPD and production manager has to know and be curious about which approach to use. In the following sub sections, we will see some of these approaches and forms of innovation in relation to NPD.

\section{Market Driven vs Driving-Market Approaches of NPD}

Beverland et al. (2006) have identified two approaches in NPD: Market Driven and Driving-Market approaches. Market-driven activities are those that seek to exploit the current market structure without changing ongoing structure through incremental adaptations of past behaviors (Jaworski et al. 2000). It usually does not lead to breakthrough innovation (Atuahene-Gima 1996). Market-driven activities are adopted as part of a formal market orientation and then new product innovation is implemented in order to increase market share. Market-oriented firms consider NPD as a core competitive capability as positional advantage is determined by the efforts of innovative purpose-driven new product development over years. Organizations in this cluster also viewed customer driven NPD as inadequate: especially, Jaworski and his colleagues argue that meeting the needs of those highly satisfied customers who are looking at no other suppliers becomes a problem if there is no new thing to offer. These firms are expected to be leaders in their fields in 
terms of relative market dominance, customer preferences, growth in sales, and margin earned relative to competitors (Atuahene-Gima 1996).

When utilizing a market-driven approach, businesses adopt a reactive stance and focus on trying to learn, understand and respond to stakeholder perceptions and behavior (Jaworski et al. 2000). In contrast, a driving-market approach involves proactive strategies that aim to change the structure of the marketplace or the rules of the game (Jaworski et al. 2000). In these approaches of NDP, the effect or role of Market and Entrepreneurial orientation on product development significantly varies. In the case of Market driven approaches, the design and the entire features of the newly developed product are influenced by the preferences, needs, wants and demand of particular group of customers who are in the target (Calantone et al. 1996). Whereas, in the case of driving market approach, NPD is mainly based on entrepreneurial orientations which includes firms' strategic directions, risk taking, pro-activeness, innovativeness and the level of aggressive competitiveness (Awang et al. 2010, Lukas and Ferrell 2000). Adopting a driving-market approach to NPD can help firms to influence the competitive environment (Parry \& Song 1994) and it supports proactive measures. Hence, industrial firms are expected to look beyond market-driven behaviors and identify new markets, and new sources of value to drive new product innovations (Beverland et al. 2006). They concluded that the most successful firms were found to be those characterized by a driving-market approach, rather than those relying solely on relationships and reacting to changing market phenomena.

\section{Customers vs Firms' Perspectives of Newness in NPD}

Literatures clearly dictate that the level of innovativeness in NPD is a major driver of profitability which determines the sustainability of a company's profitability and ensures its survival in the future (Brown \& Eisenhardt 1995, Ernst 2002) and it is a source of competitive advantage (Beverland et al. 2006). Almost all definitions of innovation start with or connect to the concept of newness; and it is "newness" that distinguishes innovation from a simple change (Rekettye 2003). In his review on the European Commission Green Paper, "innovation is defined as the successful production, assimilation and exploitation of novelty in the economic and social spheres" (European Commission 1995, as cited in Rekettye 2003, 46). Regarding product newness, Lawton and Parasuraman (1980) describe it in two perspectives. First, from the customer's perspective, product newness pertains to the extent to which an innovation is compatible with the experiences and consumption patterns of customers. Second, from the firm's perspective, degree of product newness refers to the degree of difference between an innovation and those already on the market. It is better to see here what kind of orientation a firm needs in each perspective. In case of former perspective, if it is completely new to the customers of a firm, then product innovation or development is relied more on other orientation (i.e. is, obviously, an entrepreneurial orientation) than market orientation. It is driving-market rather than market driven production innovation approach because of the change in both product and customers buying patterns (Jaworski et al. 2000).

\section{Marketing Mix vs Product Related Innovation}

The marketing mix mainly encompasses the main four P's (product, place, price and promotion). It should not be dubious, here in this case, that the development of new product or product innovation is being discussed from manufacturers' point of view. Actually, when manufacturers develop or innovate a new product, what would be changed from marketing elements, in the innovation process? Is it only a product or are other marketing mix elements included? This is the point of discussion in marketing-and-product related innovation matrix (Figure 1) constructed by Rekettye (2003). 
Figure 1. Marketing mix and product related matrix

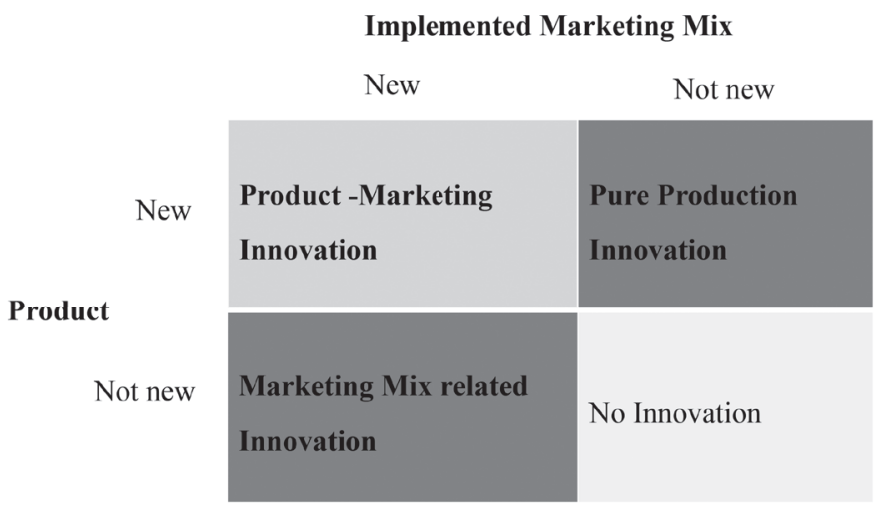

Source: Rekettye 2003

Pure product innovation ( $2^{\text {nd }}$ Quadrant): According to Rekettye (2003): pure product innovation is all about introducing new products to the customers with the help of the existing marketing infrastructure and of marketing elements. In this case, the marketing means are not changed and they have been proven to be successful in the marketing of other products. The ground behind making pure product innovation should be an attempt to tap the opportunities unrecognized by other competitors in the market (Rekettye 2003). To do this, it all needs to have opportunity identification skills and risk taking attitude rather than aversion, which signify an entrepreneurial orientation of firms (Scott \& Venkataraman 2000).

Combined marketing and product innovation ( $1^{\text {st }}$ Quadrant): When a product or service innovation of "breaking with the past"-type appears, the role of marketing is extremely complex. This type of innovation which includes both marketing mix elements and products is based on the fact that "the launching of revolutionary new products generally requires marketing innovation to be successful in the market" (Rekettye 2003, 50). Here comes the roles of $\mathrm{MO}$ and $\mathrm{EO}$, in this case in order to make brand new product and to introduce it to the market in an unfamiliar way, both types of orientation may be equally implemented. From EO, risk taking propensity, innovativeness and pro-activeness could be taken as the driving forces for this kind of innovation and from marketing side, especially, pricing and promotion may have utmost importance to introduce this product to the target customers. In fact, MO does not take to real or novel product innovation which has never ever been experienced by customers (Bennett and Cooper 1981, Slater and Narver 1995, Christensen and Bower 1996).

Marketing Mix Related innovation: According to Rekettye (2003), marketing firms, which engage in market research do not only collect and analyze data in connection with demand and market trends but also make attempt to find and develop new solutions to the observed marketing problems. Then, the necessary change may be done on any marketing elements including packaging, advertisement, and distribution and even on the price itself. Literature also indicates that MO firms are likely to develop incremental new products rather than innovative products, within existing market segments (Christensen and Bower 1996, Bennett and Cooper 1981, Slater and Narver, 1995).

\section{Continuous vs Discontinuous Innovation}

In his review, Rekettye (2003) also indicated the other approaches of Product Innovation: continuous innovation and discontinuous innovation. They can also be described as continuous and radical innovation (Cooper 1998) or incremental and radical innovation as reviewed by Iyer et al. (2006). Continuous innovation is most often done within the boundaries of existing marketing system of firms. It gets adopted if firms assume that the future competitive requirements of customers would be met within existing industry structures, an existing competitive architecture (Miller and Morris 1999, 4; as cited in Rekettye 2003, 47). On the contrary, "the typical feature of discontinuous innovation is breaking with the past, thus leading to a radical, revolutionary change" (Rekettye, 2003). Miller and 
Morris (1999) argued that this kind of innovation works outside of the existing market segments or territories. Once it gets successfully done in a certain innovation, then expands and reposition the markets and explore all new possibilities (Miller and Morris, 1999). In the former case, there would be no change in consumers consumption patterns and habits because almost all the marketing mix elements remain the same and there is no structural change. In order to realize this, a firm which makes this continuous innovation has to be more costumer or market-oriented than a firm that opts for discontinuous innovation. On the other side, a manufacturing firm opting for discontinues innovation needs to have more of entrepreneurial orientation because its needs more pro-activeness, risk taking and innovativeness in order to develop and introduce unknown product which has never been experienced by customers (Covin and Slevin I986, Saren 1985). For example, the Apple Company at the beginning did not collect customers' preferences towards its first iPad tablet, Nintendo Wii with motion sensitive controllers, because the product was not existing and unknown by customers; of course, even no customers as such (Rhee 2015).

\section{MARKET ORIENTATION AND NEW PRODUCT DEVELOPMENT}

Conflicting arguments have been made regarding the real effect of market orientation on production innovation and organizational performance. In the reviews made by some scholars, they claimed that market orientation even has adverse consequences for product innovation and organizational performance (Bennett and Cooper 1981, Atuahene-Gima 1996). With little similarity, Lawton and Parasuraman (1980) argued that, empirically, there is no evidence supporting significant relationship between MO and NPD. Bennett and Cooper (1981) justify that market orientation leads to the uncompetitive syndrome of 'me-too' products rather than breakthrough innovations. On the contrary, there are numerous theoretical and empirical researchers advocating for market orientation and supporting the argument that it leads to successful innovation and higher organizational achievement (Baker et al. 2009, Deshpande et al. 1993, Kohli and Jaworski 1990). In line with this, the others still say that MO enables only to enhance incremental innovation, not novel ones (Christensen and Bower 1996, Bennett and Cooper I981, Slater and Narver 1995). This argument was also supported by Calantone $e t$ al. (1996) and they highlighted MO's importance "to collect and assess market and competitive information in order to understand customers' needs, wants, and specifications for the product; to know customers' price sensitivity; to understand customers' purchase decisions; and to learn about competitors' strategies, strengths, and weaknesses".

Later on, Atuahene-Gima (1996) suggested in his empirical research that market orientation has a huge direct impact on the firms' innovative performance. However, they said that when it is moderated by innovative features, it would have an insignificant effect on market share success. This finding forces us to go back and see Reketytye's (2003) market-product related matrix and his review on continuous and discontinues innovation. Based on that fact, we can infer that $\mathrm{MO}$ would play significant role in the case of continuous and marketing mix related innovations. Also, Atuahene-Gima (1996) made it clear in his findings that $\mathrm{MO}$ reduces the chances of the firm producing innovations that require major behavioral changes on the part of the firm's actual and potential customers and forces them to switch off. Including Atuahene-Gima(1996), several researchers make an inference that the firm's degree of $\mathrm{MO}$ is significantly and positively associated with innovation-marketing fit, product advantage, and inter-functional teamwork and it is highly correlated with new product success (Cooper and Kleinschmidt 1987, Calantone et al. 1996, Baker et al. 2009). However, it was remarked that "market orientation is not a panacea for ineffectiveness in the innovation process or products/services lacking some fit with the firm's skills or some advantage to customers" (Atuahene-Gima, 1996). Moreover, the recent study shows that in outcome based reward it is negatively related to radical innovation (Joshi, 2016) and these factors have become a loop hole for the concept of entrepreneurial orientation to flourish and be widely accepted.

\section{ENTREPRENEURIAL ORIEN- TATION AND NEW PRODUCT DEVELOPMENT}

A higher degree of innovativeness, risk-taking and pro-activeness are three main characteristics that distinguish entrepreneurial orientation from market orientation (Covin and Slevin I986, Lukas and Ferrell 2000, Bouncken et al. 2016). Unlike $\mathrm{MO}$, the importance of EO on new product development has not been doubted but there are still studies arguing that if an entrepreneurial orientation is not coupled with customer or market orientation, 
it does not have a direct effect on product innovation (Thoumrungroje and Racela 2013). The Meta analysis of 56 studies conducted by Rauch et al. (2009) showed that EO generally has a positive effect on firm performance. The other most recent empirical study demonstrates that that entrepreneurial orientation enhances innovation adoption and generation which in turn enhance product innovation (Etriya $e t$ al. 2018). Finally, this product innovation enhances firm's revenues.

Also, according to Etriya et al. (2018), EO enables firms to innovate by taking risks in anticipating future demand, through either adoption of available innovations or generation of their own innovations and both options result in new or improved products and eventually generate revenues to firms. A very strong interrelationship among entrepreneurial orientation, breakthrough innovation and new product development performance has also been confirmed by the other study (Lee et al. 2017). Not only within a focal firm, but also in alliances, has EO been found to be a strong driver of joint product innovation (Bouncken et al. 2016). The literature suggests that firms require a new set of imperatives, such as an alignment of market and entrepreneurship orientation if they are to be successful in product innovation in these turbulent times (Attuahene-Gima and Ko 2001) and also suggests that EO and $\mathrm{MO}$ have to complement one another, at least in small businesses, to boost profitability (Baker and Sinkula 2009).

\section{CONCLUSION AND IMPLICATION}

The effect of MO and EO on firm performance as well as profitability is widely documented in literature. This study especially focuses on New Product Development, not in a general firm performance. Perhaps, the general performance of a firm stems from the products or services a company develops and offers for sale in the market. To analyze and evaluate the effect of $\mathrm{MO}$ and $\mathrm{EO}$, new product development is studied from manufacturers' point of view. In this brief writing, the attempt was made to identify the different forms and approaches of innovation in New Product Development and to explain how it has been influenced by $\mathrm{MO}$ and EO. The reviewed literature revealed four main, somewhat overlapping, forms and approaches of product innovation in NDP which enables us to see the distinct roles of MO and EO. These forms and approaches of innovation: Continuous versus Discontinuous Product Innovation; Market-Driven versus Driving-Market Innovation; Marketing Mix versus Product Related Matrix Innovation; Customers versus Firms' Perspective Newness (innovation) approach.

In a case of discontinuous (also called disruptive or radical) innovation, driving-market innovation, pure product innovation, literature adequately supports the view that EO plays a predominant role in NPD. Discontinuous innovation makes real disruption in customers' buying preferences and wants by introducing products which have never been experienced by the existing customers. If product innovation is totally new in both firms' and customers' perspectives, it can be considered as ground breaking innovation which also comes under discontinuous or disruptive innovation. Such kind of innovation in NDP comes from a firm's strategic entrepreneurial orientation of innovativeness, risk taking and pro-activeness. Whereas, in the case of continuous (also called incremental) innovation, market-driven innovation and marketing- mix related innovation, MO takes a lion share in providing firms with updated market information that can be useful for innovation or product development decision. Therefore, for researchers or practitioners, the question here should not be whether MO and EO have an effect on NDP or not; because, obviously, both of them have an effect on NPD but in different ways for different innovation approaches and forms. Rather, the question should be on the approaches and forms of innovation adopted in NDP in which $\mathrm{MO}$ and EO most likely influence, which is already attempted to articulate in this paper. The researcher suggests practitioners to rely on either MO or EO or both based on firms' strategic decision regarding the approaches and forms to be adopted for NPD. Further research can be done regarding the unique roles of $\mathrm{EO}$ and $\mathrm{MO}$ in service sector organization and social enterprises innovation approaches. 


\section{REFERENCES}

Atuahene-Gima, K. (1996), "Market orientation and innovation", Journal of Business Research, 35 2, 93-103 DOI: https://doi.org/10.1016/01482963(95)00051-8

Atuahene-Gima, K. and Ko, A. (2001), “An Empirical Investigation of the Effect of Market Orientation and Entrepreneurship Orientation Alignment on Product Innovation", Organization Science, 12 1, 54-74 DOI: https://doi.org/10.1287/ orsc.12.1.54.10121

Awang, A., Ahmad, Z. a., Abdul Rashid, A. S., and Subari, K. A. (2010), "Entrepreneurial Orientation among Bumiputera Small and Medium Agro-Based Enterprises (BSMAEs) In West Malaysia: Policy Implication in Malaysia, International Journal of Business and Management, 130-43 DOI: https://doi.org/10.5539/ijbm. v5n5p 130

Baker, W. E. and Sinkula, J. M. (2009), “The complementary effects of market orientation and entrepreneurial orientation on profitability in small businesses", Journal of Small Business Management, 47 4, 443-64 https://doi.org/10.1111/ j.1540-627x.2009.00278.x

Bennett, R.C. and Cooper, R. G. (1981), "The misuse of marketing: An American tragedy", Business Horizons, 24 6, 51-61 DOI: https://doi. org/10.1016/0007-6813(81)90026-4

Beverland, M. B., Ewing, M. T., Matanda, M. J. (2006), "Driving-market or market-driven? A case study analysis of the new product development practices of Chinese business-to-business firms", Industrial Marketing Management, 35 3, 383-93 https://doi.org/10.1016/j.indmarman.2005.02.008

Bouncken, R. B., Plüschke, B. D., Pesch, R., Kraus, S. (2016), "Entrepreneurial orientation in vertical alliances: joint product innovation and learning from allies", Review of Managerial Science, $\mathbf{1 0}$ 2, 381-409 DOI: https://doi.org/10.1007/s11846014-0150-8

Brown, S. L., Eisenhardt, K. M. (1995), "Product Development: Past Research, Present Findings, and Future Directions," Academy of Management Review, 20 2, 343-78 DOI: https://doi. org/10.2307/258850

Calantone, R. J., Schmidt, J. B. and Song, X. M. (1996),"Controllable factors of new product success: A cross-national comparison", Marketing Science, 15 4, 341-58 DOI: https:/doi. org/10.1287/mksc. 15.4 .341
Cooper, J. R. (1998), “A Multidimensional Approach to the Adoption of Innovation," Management Decision, 36 8, 493-502 DOI: https:/doi. org/10.1108/00251749810232565

Cooper, R. G. \& Kleinschmidt, E. J. (1987), "New products: What separates winners from losers?", The Journal of Product Innovation Management, 4 3, 169-84 DOI: https://doi.org/10.1016/07376782(87)90002-6

Covin J. G. (1991), "Entrepreneurial Vs Conservative Firms; comparison of strategy and Performance", Journal of Management Studies, 28(5); 439-462 DOI: https://doi.org/10.1111/j.1467-6486.1991. tb00763.x

Covin, J. G. \& Slevin, D. P. (1986), “The Development and Testing of an Organizational-Level Entrepreneurship Scale", in Ronstadt, R. (ed.), Frontiers of Entrepreneurship Research, 1986: Proceedings of the Sixth Annual Babson College Entrepreneurship Research Conference Wellesley, Mass: Center for Entrepreneurial Studies, Babson College, 628-39

Christensen, C. M. and Bower J. L. (1996), "Customer Power, Strategic Investment and Future of Leading Firms", Journal Strategic Management, 17 197-218 DOI: https://doi.org/10.1002/ (sici)1097-0266(199603)17:3<197::aid-smj804>3.3.co;2-1

Deshpandé, R., Farley, J. U. \& Webster Jr, F. E. (1993), “Corporate Culture, Customer Orientation, and Innovativeness in Japanese Firms: A Quadrad Analysis", Journal of Marketing, 57 1, 23-37 DOI: https://doi.org/10.2307/1252055

Ernst, H. (2002), "Success factors of new product development: A review of the empirical literature", International Journal of Management Reviews, 4 1, 1-40 DOI: https://doi. org/10.1111/1468-2370.00075

Etriya, E., Scholten, V. E., Wubben, E. F. M., Kemp, R. G. M. \& Omta, S. W. F. (2018), "The importance of innovation adoption and generation in linking entrepreneurial orientation with product innovation and farm revenues: The case of vegetable farmers in West Java, Indonesia", International Food and Agribusiness Management Review, 21 7, 969-88 DOI: https://doi. org/10.22434/ifamr2017.0038

Frishammar, J. (2005), "Managing Information In New Product Development: A Literature Review", International Journal of Innovation \& Technology Management, 2 3, 259-75 DOI: https://doi.org/10.1142/s021987700500054x

Griffin, A. (1997), "PDMA research on new product development practices: Updating trends and benchmarking best practices", Journal of Prod- 
uct Innovation Management, 14 6, 429-58 DOI: https://doi.org/10.1111/1540-5885.1460429

Iyer, G. R., LaPlaca, P. J., Sharma, A. (2006), "Innovation and new product introductions in emerging markets: Strategic recommendations for the Indian market", Industrial Marketing Management, 35 3, 373-82 DOI: https://doi. org/10.1016/j.indmarman.2005.02.007

Jaworski, B., Kohli, A. K., Sahay, A. (2000), "Market-driven versus driving markets", Journal of the Academy of Marketing Science, 28 1, 45-54

Joshi, A. W. (2016), "When Does Customer Orientation Hinder (Help) Radical Product Innovation? The Role of Organizational Rewards", Journal of Product Innovation Management, 33 4, 435-54 DOI: https:/doi. org/10.1177/0092070300281005

Kohli, A. K. and Jaworski, B. J. (1990), "Market Orientation: The Construct, Research Propositions, and Managerial Implications", Journal of Marketing, 54 2, 1-18 DOI: https://doi. org/10.2307/1251866

Lawton, L. and Parasuraman, A. (1980), “The Impact of the Marketing Conception on New Product Planning", Journal of Marketing, 44 Winter, 19-25 DOI: https://doi.org/10.2307/1250030

Lee, S-M., Li, C-Y., Tsai, C-Y. (2017), “Achieving new product development performance through entrepreneurial orientation: evidence from Taiwan", International Journal of Technology, Policy and Management: IJTPM, 17 4, 337-59 DOI: https://doi.org/10.1504/ijtpm.2017.10007684

Lukas, B. A. \& Ferrell, O. C. (2000), "The effect of market orientation on product innovation", Journal of the Academy of Marketing Science, 282 , 239-47

Lumpkin, G. T., Dess, G. G. (1996), “Clarifying the entrepreneurial orientation construct and linking it to performance", Academy of Management Review, 21 1, 135-72 DOI: https://doi. org/10.2307/258632

Miller, W. L. \& Morris, L. (1999), 4th generation $R \& D$ : managing knowledge, technology, and innovation. New York [u.a.].

Mohr, J. J., Sengupta, S. \& Slater, S. F. (2010), Marketing of high-technology products and innovations. Translated from English by Upper Saddle River, NJ [u.a.].

Parry, M. E. \& Song, X. M. (1994), "Identifying new product successes in China", The Journal of Product Innovation Management, 11 1, 15-30 DOI: https://doi.org/10.1016/07376782(94)90116-3

Rauch, A., Wiklund, J., Lumpkin, G. T. \& Frese, M. (2009), "Entrepreneurial orientation and business performance: An assessment of past research and suggestions for the future", Entrepreneurship: Theory and Practice, 33 3, 761-87 DOI: https:// doi.org/10.1111/j.1540-6520.2009.00308.x

Rekettye, G. (2003), "The Regularities of Innovation - A marketing perspective",. Acta Oeconomica, 53 1, 45-59 DOI: https://doi.org/10.1556/ aoecon.53.2003.1.3

Rhee, B. V. D. (2015), Innovate or Perish: New Product Development as a Key Domain af Operations Management, Inaugural Lecture, Nye Rode Business University

Saren (1985), "Corporate innovation: marketing and strategy: Gordon Foxall, Croom Helm, Beckenham, 1984. pp. 276." Book review, Journal of Economic Psychology, 6 2, 207-10 DOI: https:// doi.org/10.1016/0167-4870(85)90022-4

Schilling, M. A. \& Hill, C. W. L. (1998), "Managing the new product development process: Strategic imperatives", Academy of Management Executive, 12 3, 67-81 DOI: https://doi.org/10.5465/ ame.1998.1109051

Scott, S. \& Venkataraman, S. (2000), “The Promise of Entrepreneurship as a Field of Research", The Academy of Management Review, 25 1, 217-26 DOI: https://doi.org/10.5465/amr.2000.2791611

Slater, S. F. \& Narver, J. C. (1995), "Market Orientation and the Learning Organization", Journal of Marketing, 59 3, 63 DOI: https://doi. org/10.2307/1252120

Slater, S. F., Sengupta S., Mohr J. J. (2010), Marketing of high-technology products and innovations. Research Gate, Electronic Version, https://www. researchgate.net/publication/230052811 (Downloaded: 27/07/2019)

Thoumrungroje, A., Racela, O. (2013), "The contingent role of customer orientation and entrepreneurial orientation on product innovation and performance", Journal of Strategic Marketing, 21 2, 140-59 DOI: https://doi.org/10.1080/0965 254x.2012.742129

Zahra, S. A. (1991), "Predictors and Financial Outcomes of Corporate Entrepreneurship: An Exploratory Study," Journal of Business Venturing, 6 4, 259-85 DOI: https://doi. org/10.1016/0883-9026(91)90019-a

Adisu Fanta Bate, PhD student adisufanta@gmail.com

Faculty of Business and Economics University of Pecs, Hungary 